\title{
Cost effective analysis of milk production in Gujarat, India
}

\author{
H. Sharma*, S.S. Kalamkar and M.C. Makwana
}

Agro-Economic Research Centre, Sardar Patel University, Vallabh Vidyanagar, Anand, Gujarat

*Corresponding author: sharmah007@gmail.com

Journal of Livestock Science (ISSN online 2277-6214) 13: 20-24

Received on 10/9/21; Accepted on 18/12/21; Published on 8/1/22

doi. 10.33259/JLivestSci.2022.20-24

\begin{abstract}
Present study conducted to assessment the cost-effective analysis of dairy in Gujarat state. Out of 120 selected sample, around 55 per cent animals were milch animals, the highest share was of buffalo (43.3\%), followed by crossbreed $(32.1 \%)$ and cows $(23.8 \%)$. The species wise total cost of maintenance of a milch animal of cattle's and buffalo was estimated to be Rs. 194.4 and 203.5 per animal per day but per litter buffalo milk of cost was lower than the cattle animals. On an average, net return of about Rs. 45/- per buffalo animal per day was realized by the selected households as compared to Rs. 27.41 to 35.34/- per local and cross breed animal per day realized by the selected households. Low margins may be due to low milk productivity from milch cattle animals with low genetic potential, poor health, and feeding and husbandry practices low price offered by private agent/agency.
\end{abstract}

Key Words: Buffalo; Cattle; Cost; Dairy; Milk; and Return 


\section{Introduction}

Animal husbandry has been playing an important role in boosting the agrarian economy of the state. About 42 per cent families keep livestock in Gujarat as a source of income. Live stock and milch animal are the main support of agricultural operations and also a major source of supplementary income to the marginal and small farmer and landless agricultural laborers. On the other hand, the by-products of agricultural produce happen to be the chief ingredients of food for cattle and milch animals. Farmers are in a position to follow animal husbandry and dairying as an adjunct to cultivation. The requisite labour for keeping dairy animals is also available from within the farmer's family. Gujarat state has leading state in dairy cooperative sector in India. Cooperatives and dairy companies are expanding their network to meet the current growing demand of the population but the organized sector comprises only of 20 percent of the total milk production (Intodia, 2016). Rest is completely unorganized. This shows that Indian dairy industry has a huge untapped market to explore. Recently, in context of doubling farmers' income, Prime Minister Shri Narendra Modi has also emphasized on presence of tremendous opportunities in animal husbandry. According to NSSO survey conducted in January-December 2013, around 1.75 percent of the total rural households derived the major income from self-employment in livestock farming. Milk production is an integral part of farming system in India. Most of the milk producers in India are small and marginal, mainly consisting of 1-2 animals, due to which it is characterized by low input-low output system. The $20^{\text {th }}$ Livestock census-2019 of India has placed total livestock population at 536.76 million, out of which, 26.9 million livestock population was in the state of Gujarat. The state accounts for 4.98 per cent share in cattle population, 9.60 per cent of buffalo population, 2.41 per cent sheep population and 3.27 per cent goat population of the country. Among the species, buffalo contributes highest share (39.19\%) in total livestock population followed by Cattle (35.81\%), Goat (18.10 $\%)$ and Sheep $(6.64 \%)$. The females among the indigenous cattle, crossbred and buffalo population numbered 4.38 million, 3.27 million and 10.01 million, respectively. There is a decrease of $(-0.87)$ per cent in livestock population in 2019 over 2012. The highest growth in population was recorded in population of sheep (4.64\%) and buffalo $(1.51 \%)$, while cattle and goat population registered decline. Therefore, the present study was undertaken in the state of Gujarat which is the leading milk producer in the country with cooperative dairy sector well established, but growth in dairy is not uniform in all regions of the state. Keeping the above conditions in mind, it is essential to study the cost-effective investigation of milk production of cattle and buffalo milch animals sector in Gujarat.

\section{Material and methods}

Present study conducted to assessment the cost- benefit analysis of Milk Production by the milk producers were selected from four regions of the Gujarat state, i.e. North(Mahsana district),South (Bhruch district), West (Junagarh district) and East (Panchmahal district) Gujarat and 30 milk producer were selected from each district. Total 120 Milk Producer selected from selected region. The cost and returns analysis was carried out different variable like feed \& fodder, veterinary labour charges and milk production.

\section{Analytical tools}

In order to analyze the operational expenses/variable cost/paid out cost/direct cost in dairy farming the following details were tabulated.

Feed Cost: The cost incurred on green fodder, dry fodder, concentrate and supplements to feed the animals constitutes feed cost. It was calculated by multiplying quantities of feed and fodder consumed by animals with the respective prevailing market rate/s for feed and fodder in the study area.

Labour Cost: It includes family labour as well as paid hired labour. The hired labour cost was calculated considering time utilised in various dairy activities and wages paid. In case of family labour, prevailing wage rate of casual labour in the study area was considered.

Veterinary Cost: It includes the annual cost incurred on natural service, Artificial Insemination (A.I.), vaccination, de-worming, medicines and other charges/fees of veterinary doctors.

Miscellaneous Costs: The cost on water charges, electricity, repairs of machines, bucket, transport cost, rope, etc constituted this cost.

Returns: The returns from milk production and animal were taken into consideration for computing the gross returns. The returns from the sale of animals (except for salvage value) are not accounted for while estimating the returns from milk production.

Gross returns $=$ Quantity of milk $\times$ market price of milk

Net returns: Net return was calculated by subtracting net cost from gross returns

$$
\text { Net returns }=\text { Gross returns }- \text { Net cost }
$$

Cost of Milk Production: All the costs were calculated for per animal per day which indicates the cost of maintaining an animal per day. 


\section{Results and Discussion}

\section{Breedable Animals}

The details on herd strength and cattle shed are presented in tables 1 . It can be seen from the Table, that all together, every households has the highest share of buffaloes, followed by local cows and then cross bred cows in total herd strength. Out of total herd strength with household, around 55 per cent animals were milch animals, the highest share was of cross breed $(78.6 \%)$, followed by buffaloes $(58.6 \%)$ and cows $(52.5 \%)$.

On the date of survey, the information was collected on numbers of breedable animals with the selected households and presented in Tables 2. It can be seen from tables that on an average, the age of local and cross bred cows was around 5-6 years and for buffaloes, it was around 7 years. The age at first calving of local cattle (40-41 months) was found higher than crossbred cows (31-34 Months). The average age of first calving ranges from 3141 months in case of cows and 42-44 months in case of buffalos. The lactation order of the milch animal was found to be either 2 or 3 . The average level of peak yield recorded during the present lactation was marginally lower than earlier lactation in case of cross breed cows of selected households, while same were found marginally higher in local cows and buffalos. Across the species, the milk yield of local cows and buffaloes during present lactation was found higher in selected households. The similar findings were observed by Sharma et al (2021). However, as mentioned earlier, the milk yield of cross breed cows was the highest followed by buffaloes and local cows.

\section{Cost of Milk Production}

The overall total cost of maintenance of a milch animal of selected milch animal was calculated to be Rs. 196.40 per animal per day but highest variable cost was calculated Rs.. 203.50 per animal per day in case of buffalo animal followed by Cross breed and Local cow was about Rs.194.4 and Rs.191.4 per day per animal (Table 3). About 61.34 per cent of the cost was on feed and fodder which is a major component of the total milk production cost. Which is consistent with the earlier studies carried out in different states by Lal and chandel (2016) at Haryana, Meena et al (2012) at Rajasthan and Sharma and Kalamkar (2020) at Rajasthan. In case of buffalo, the feeds and fodder cost accounted for around 62.80 percent of the total cost. In feeding Buffalo milch animal the cost incurred per day on green fodder, dry fodder, concentrates and supplements were Rs. 31.60, Rs. 27.40, Rs. 62.9 and Rs 2.48 respectively. The cost of per litre was lowest was observed in case of buffalo as compared to local and cross bred milch animal. This is in conformity with the earlier studies carried out by Sharma and Kalamkar (2021), Sharma et al (2020).

\section{Milk Production and return}

On an average, Rs. 34.4/ litre price was realised by the households, the highest was in case of Rs. 35.0/litre in case of buffalo and the lowest of Rs. 34.1/litre in case of local and cross breed cows. The highest average price received by the milk producer towards sale of milk to consumer and Private vendor followed by sale to retail shop and the lowest was when it was sold to sweet shop. The most of consumers preferred buffalo milk and they ready to pay high price for quality milk. From the table 4 milk production and return, on an average, net return of about Rs. 45.4/- per animal per day was realized by the buffalo animals as compared to Rs. 27.41 to 35.34/- per animal per day realized by the other cattle (Local and Cross bred). The net return realized by the buffalo category was higher by 60 per cent at overall level.

Table 1: Details on Herd Strength

\begin{tabular}{|l|c|c|}
\hline Particulars & Total Animal (No.) & Milch Animal (No) \\
\hline Local Cattle & 217 & 114 \\
\hline Cross Bread & 196 & 154 \\
\hline Buffalo & 355 & 208 \\
\hline Other & 97 & 4 \\
\hline Total & 865 & 480 \\
\hline
\end{tabular}

Source: Field Survey Data; Note: other (Goat)

Table 2: Details of breedable animals with selected Households on Survey Date

\begin{tabular}{|c|l|c|c|c|}
\hline No & Particulars & Local Cow & Crossbred Cow & Buffalo \\
\hline 1 & Av. Age (year) & 6 & 6 & 7 \\
\hline 2 & Av. Age at I ${ }^{\text {st Calving Month) }}$ & 41 & 31 & 44 \\
\hline 3 & Lactation Order@ & 2 & 3 & 3 \\
\hline 4 & Lactation Period (Days) & 235 & 248 & 244 \\
\hline 5 & Peak Yield- & & & \\
\hline & Last Lactation & 6.7 & 10.8 & 9.6 \\
\cline { 2 - 5 } & Present Lactation & 6.9 & 10.6 & 10.1 \\
\hline
\end{tabular}

Source: Field Survey Data 
Table 3: Cost of Milk Production of Selected species in Gujarat

\begin{tabular}{|l|l|l|l|l|l|}
\hline \multirow{2}{*}{ No. } & Particulars & \multicolumn{2}{l|}{ pecies wise cost of milk production } \\
\cline { 3 - 6 } & & Local Cow & Crossbreed Cow & Buffalo & All \\
\hline 1 & Total Dry Fodder (Rs./Animal/Day) & $31.3(16.35)$ & $30.9(15.90)$ & $31.6(15.53)$ & $31.3(15.92)$ \\
\hline 2 & Total Green Fodder (Rs./Animal/Day) & $24.2(12.64)$ & $25(12.86)$ & $27.4(13.46)$ & $25.5(13.00)$ \\
\hline 3 & Total Concentrates (Rs./Animal/Day) & $55.7(29.10)$ & $56.1(28.86)$ & $62.9(30.91)$ & $58.2(29.65)$ \\
\hline 4 & Total Supplements (Rs./Animal/Day) & $4.4(2.12)$ & $6.1(2.84)$ & $5.9(2.48)$ & $5.5(2.48)$ \\
\hline 5 & Total feed \& fodder (Rs./Animal/Day) & $115.6(60.40)$ & $118.1(60.75)$ & $127.8(62.80)$ & $120.5(61.34)$ \\
\hline 6 & Total Labour (Rs./Day) & & & & \\
\hline & Male (Rs./Day) & $46.3(24.19)$ & $46.3(23.82)$ & $46.3(22.75)$ & $46.3(23.57)$ \\
\hline & Female (Rs./Day) & $28.0(14.63)$ & $28.0(14.40)$ & $28.0(13.76)$ & $28.0(14.25)$ \\
\hline & Total & $74.3(38.82)$ & $74.3(38.22)$ & $74.3(36.51)$ & $74.3(37.82)$ \\
\hline 7 & Veterinary Cost (Rs./Animal/Day) & $1.5(0.78)$ & $2(1.03)$ & $1.4(0.69)$ & $1.6(0.83)$ \\
\hline 8 & Total Cost (Rs./Animal/Day) & $191.4(100)$ & $194.4(100)$ & $203.5(100)$ & $196.4(100)$ \\
\hline 9 & Milk Production (Litre/Animal) & 6.1 & 6.3 & 6.8 & 6.4 \\
\hline 10 & Per litre Cost & 31.4 & 30.9 & 29.9 & 30.7 \\
\hline
\end{tabular}

Source: Field Survey Data; Note: parenthesis indicates the percentage share of total Cost

Table 4: Spices wise Milk Production and Returns in dairy milch animals

\begin{tabular}{|l|l|c|c|c|c|}
\hline \multirow{2}{*}{ No. } & \multirow{2}{*}{ Particulars } & \multicolumn{4}{|c|}{ Spices wise Milk Production and Returns } \\
\cline { 3 - 6 } & & Local Cow & Crossbreed Cow & Buffalo & All \\
\hline 1 & Milk Production (Litre/Animal) & 6.1 & 6.3 & 6.8 & 6.4 \\
\hline 2 & Price (Rs. /litre) & 34.1 & 34.1 & 35 & 34.4 \\
\hline 3 & $\begin{array}{l}\text { Returns from Milk Production } \\
\text { (Prodn*Avg Price) }\end{array}$ & 208.01 & 214.83 & 238 & 220.3 \\
\hline 4 & Income from Dung (Rs./Animal/Day) & 10.8 & 11.5 & 10.9 & 11.1 \\
\hline 5 & Total Income (Rs./Animal/Day) & 218.81 & 229.74 & 248.9 & 232.5 \\
\hline 6 & Net Return/ Profit (Rs./Animal/Day) & 27.41 & 35.34 & 45.4 & 36.1 \\
\hline & Net Return/liter (Rs./Animal/Day) & 2.7 & 3.2 & 5.1 & 3.7 \\
\hline
\end{tabular}

The highest net return by selected households was recorded in case of buffaloes, followed by crossbred cows and lowest was in case of local cows due to most of have good buffalo breed Murrah and Bhadawari which have good quality of fat content. The similar results revealed by Gill and Singh (1986), Vashist and Katiha (1988), Shah et al (1996), Sharma and Kalamkar (2020) Kalamkar et al (2021). Therefore, there is a huge scope to enhance producers' income from dairy by enhancing animals' productivity, improving management practice, and ensuing remunerative prices.

\section{Conclusions and Policy Recommendation}

From the study, it was observed that all together, every selected household has the highest share of buffaloes, followed by local cows and then cross bred cows in total herd strength. Out of total herd strength with selected household, around 55 per cent animals were milch animals. In selected milch animal, the age of local and cross bred cows was around 5-6 years and for buffaloes, it was around 7 years. The overall total cost of selected cattle and buffalo milch animals was calculated to be Rs. 194.4 and 203.5 per animal per day but per litter buffalo milk of cost was lower than the cattle animals. The net returns realised by the buffalo milch animals was higher than other dairy cattle's. Low margins for dairy producers may be due to low milk productivity from cattle animals with low genetic potential, poor health, and feeding and husbandry practises low price offered by private agent/agency. Livestock sector occupies a pivotal position in the Indian economy and its contribution to the agricultural sector is the highest, the plan investments made so far do not appear proportionate with its contribution and future potential for growth and development. This suggests that public investment in the livestock sector should be enhanced to help the smallholder livestock producer, which deprives their larger share of income from the livestock sector. The livestock services like artificial insemination/natural service, vaccination, de-worming, etc are time-sensitive and government institutions are not able to deliver in time due to financial as well as bureaucratic constraints. Therefore, there is a need to re-orient the government policy for delivery of livestock services and involve major stakeholder.

\section{References}

1) Gill, G.S. and J. Singh 1986. An economic analysis of milk production system in different agro-climatic region of Punjab. Indian Journal. of Ecology, 13(1): 52-59.

2) Hemant Sharma and S.S. Kalamkar (2021) Analysis of Milk Marketing Chain in selected States of India. Indian Journal of Agricultural Marketing (Spl issue). 35(2): 68-87 
3) Intodia, Vijay (2016). India, Dairy and Products Annual. Global Agricultural Information Network (GAIN) Report. USDA Foreign Agricultural Services. Report No.- IN6126.

4) Kalamkar, S.S., Hemant Sharma and V. G. Atkare (2021) Study on Collective Livestock Fodder Marketing Model in Aroli Village of Nagpur District of Maharashtra. Indian Journal of Agricultural Marketing. (Conf. Issue)35(1): 96-105

5) Lal Priyanka and Chandel B.S. (2016) Economics of milk production and cost elasticity analysis in Sirsa district of Haryana. Economic Affairs, 61(3): 405-411.

6) Meena,G.L., S.S.Burark,D.C Pant, Hemant Sharma and R.K. Yogi. 2012. Milk Production Function and Resource Use Efficiency in Alwar District of Rajasthan. International Journal of Scientific \& Technology Research, 1(8):115-119

7) Shah D, DK Jain and KNS Sharma, 1996 Impact of dairy cooperatives on marketing pattern of milk in Bullandshahar district. Indian Dairyman, 48 (6): 37-41.

8) Sharma, H., Kalamkar, S. S., Makwana, M. C., \& Parihar, T. B. (2020). Comparative Study of Socio-Economic Status and Constraints Faced by Members and Non-Members Milk Producers of Dairy Cooperatives in Rajasthan. International Journal of Livestock Research, 10(12), 225-233

9) Sharma, H., M.C. Makwana and S.S. Kalamkar (2021) Constraints faced by the members of organised and unorganized sector of milk producers in Gujarat. Journal of Livestock Science. 12: 23-30

10) Sharma,Hemant and S.S. Kalamkar, 2020. A Comparative Economic Analysis of Milk Production of Dairy Cooperatives Society and Non-Dairy Cooperatives Society Household of Rajasthan. Indian Journal of Economics and Development. 16(SS):17-27.

11) Vashist, G.D. and P. Katiha, 1988. A comparative economic analysis of milk production for different milch animals in Himachal Pradesh. Agricultural Situation in India. 43(2): 133-138. 